\title{
Salmon lice dispersion in a northern Norwegian fjord system and the impact of vertical movements
}

\author{
I. A. Johnsen*, L. C. Asplin, A. D. Sandvik, R. M. Serra-Llinares \\ Institute of Marine Research, PO Box 1870 Nordnes, 5817 Bergen, Norway
}

\begin{abstract}
The abundance and distribution of salmon lice Lepeophtheirus salmons originating from fish farms in a northern Norwegian fjord during the summer of 2010 was investigated by means of a numerical model, underpinned by field observations. In order to evaluate the robustness of the simulated distribution of the lice, we re-ran the simulation several times, changing the vertical responses of the lice to environmental cues such as light and turbulence, in addition to altering their vertical swimming velocity. The model was able to realistically reproduce the observed currents and stratification in the region. The simulated distribution of lice was not sensitive to different implementations of surface light nor to the light sensitivity level of the lice. However, the vertical swimming velocity and a mixing parameter influenced both their vertical distribution and horizontal dispersion. The aggregation of lice along land was influenced by their response to turbulent water. The simulated infectious stages of the lice were transported on average 20 to $45 \mathrm{~km}$ from their release site. The simulated concentrations of infectious lice varied in synchronisation with lice infestations observed on wild fish in the area. Less than $1 \%$ of the simulated lice reached a farm site. The ratio between internal and external exposure ranged from 7 to $57 \%$. Farms in the north of the fjord system were more exposed to lice released in the south than vice versa.
\end{abstract}

KEY WORDS: Salmon lice - Lepeophtheirus salmonis · Dispersion · Fjord · Aquaculture management $\cdot$ IBM $\cdot$ Model

\section{INTRODUCTION}

The salmon louse Lepeophtheirus salmonis is a naturally occurring parasite in the northern hemisphere that feeds on the skin, fat and mucus of salmonid fish (Pike 1989, Dawson et al. 1998, Pike \& Wadsworth 1999). With the industrialization of aquaculture, the numbers of potential hosts have increased, leading to unnaturally high lice infestations on both farmed and wild fish (Finstad et al. 2000, Bjorn et al. 2001, Heuch \& Mo 2001, Heuch et al. 2009, 2011). Lice levels are closely monitored at fish farms. At the time of this study, delousing was required if the level exceeded an average of 0.5 adult female lice per fish (Directorate of Fisheries 2013). On individual farms, different initiatives are being

${ }^{*}$ Corresponding author: ingrid.johnsen@imr.no taken to minimize infestations, such as the use of cleaner fish or lice skirts. The combination of delousing and preventive actions ensures that the farms are capable of keeping the number of lice within the permitted limit; however, it is expensive, time consuming, stressful for the fish and can result in the release of harmful chemicals into the environment (McHenery et al. 1991, Burridge et al. 2010). Moreover, even with these actions in place, large amounts of salmon lice are regularly observed on wild fish in Norway, and these infestations frequently influence stock size in exposed areas (Bjorn et al. 2001). Today, Norway has the largest aquacultured production of salmonid fish in the world, exceeding 1.2 million $t$ of fish sold annually. Both the aquaculture industry and the Norwegian government want a sustainable

() The authors 2016. Open Access under Creative Commons by Attribution Licence. Use, distribution and reproduction are unrestricted. Authors and original publication must be credited. 
increase in production (Ministry of Trade Industry and Fisheries 2015); however, the potential negative effects of salmon lice on wild fish populations (salmon, sea trout and Arctic char) is regarded as one of the most serious limitations to sustainable growth (Taranger et al. 2014a).

Salmon lice carry eggs in 2 eggstrings at the rear of the body. When these eggs hatch, the lice are released in the water, where they go through 2 noninfectious nauplii stages before reaching the copepodid stage. At this stage they are able to-and are crucially dependent on-infecting salmonid fish. During these stages, lice are planktonic and drift with the currents. Due to their relatively long planktonic phase (Johnson \& Albright 1991, Stien et al. 2005), information about the movement of the currents is crucial in order to determine the transport routes and residence areas of the lice. Temporal and spatial variability are high, thus the best estimates of 3dimentional environmental variables (i.e. temperature, salinity and currents) can be achieved from numerical models, validated through field observations.

Salmon lice have the ability to swim vertically in the water column and are observed to reside close to the surface (Heuch et al. 1995, Gravil 1996, Penston et al. 2004, 2008). The motivation for these vertical movements is probably to avoid predators and to seek host-rich environments (Bron et al. 1993). Nauplii reside deeper in the water column than the copepodids, and recent studies have suggested that nauplii may reside even deeper during the winter than summer (Gravil 1996, Penston et al. 2008, Johnsen et al. 2014, á Norði et al. 2015). Norwegian fjords generally exhibit a large vertical gradient in temperature, salinity and currents in the upper $20 \mathrm{~m}$ of the water column-exactly where we assume the planktonic salmon lice to reside. Hence knowing the vertical position of the lice is important in order to simulate realistic lice dispersion (Johnsen et al. 2014).

As shown in previous studies, we have developed a numerical modelling system to estimate the dispersion of salmon lice hatched on fish farms (Asplin et al. 2004, 2011, 2014, Johnsen et al. 2014). The system consists of several separate models that compute forcing and boundary conditions for the overall fjord model, estimating current and hydrography with high resolution both in time $(\mathrm{h})$ and space $(\sim 200 \mathrm{~m})$ (Albretsen 2011). These variables are used to drive the salmon lice growth and transportation model, providing hourly density fields of infective lice.

Dispersion modelling for salmon lice has seen recent, rapid proliferation (Asplin et al. 2004, 2011, 2014, Murray \& Gillibrand 2006, Gillibrandt \& Willis
2007, Amundrud \& Murray 2009, Murray et al. 2011, Stucchi et al. 2011, Adams et al. 2012, Salama et al. 2013, 2015, Stormoen et al. 2013, Johnsen et al. 2014). The models are widely used to calculate dispersion distance and the area of influence of salmon lice from single farms, to map high concentration areas in larger fjord or loch systems and to identify the exposure connectivity between fish farms. With increasing computer resources, most models have become more sophisticated with increasing quality in terms of the forcing of wind and freshwater and boundary conditions towards the coast.

A general challenge with salmon lice dispersion models is that they calculate the density of salmon lice. This represents the exposure or the infectious dose, whereas what usually is needed for management is the actual number of lice on individual fish (i.e. the response of this dose). The infectivity of salmon lice depends on salinity, temperature, the age of the copepodid and the swimming speed of the host (Bron et al. 1993, Tucker et al. 2000, Bricknell et al. 2006, Samsing et al. 2015). Thus, it is not necessarily simply a linear relationship between the number of copepodids in a region and the infection of salmonid fish.

In this paper, we present a novel approach to downscale the simulated lice density and relate it to infections found on wild fish. Our objective was to test the applicability of our salmon lice dispersion modelling system in a northern Norwegian fjord system. We have found good agreement between similar models and lice infection on fish in the southern part of Norway (A. D. Sandvik et al. unpubl data), but there are a few potentially important differences in conditions between the southern and northern regions. There is a different light regime in northern Norway, with midnight sun occurring during the summer months. In addition, water temperatures are normally lower there compared to further south. There are generally more lice in the south; during 2010 and 2012 the observed prevalence (the proportion of the fish infested with lice) of salmon lice infestation was on average the same in Folda as in the Hardangerfjord further south $\left(\sim 60^{\circ} \mathrm{N}\right)$; however, the intensity (the number of lice on the infested fish) was almost 3 times higher in the Hardangerfjord than in Folda (Taranger et al. 2014b). Topographically, there are differences between the north and south, with smaller and wider fjords to the north. These factors were all included in our circulation model.

To determine the ability of the model to predict lice densities in a northern Norwegian fjord we first compared the model-estimated circulation with available 
observations. This was done to ensure high quality forcing for the lice model. We then examined the sensitivity of the salmon lice model to light response and vertical swimming velocity as well as how turbulence in the water masses affected the dispersion of the salmon lice. The simulated distribution of the salmon lice was evaluated by comparing it to observed infestations on wild fish caught in the area. Finally, we discuss how the different farms in the fjord were exposed to salmon lice.

\section{MATERIALS AND METHODS}

\section{Area description}

The Folda fjord system is located in the northern region of Norway at $\sim 67^{\circ} \mathrm{N}$ and stretches in from the large oceanic bay Vestfjorden east of the Lofoten archipelago (Fig. 1). The fjord has 2 distinct branches: Sørfolda to the south and Nordfolda to the north.

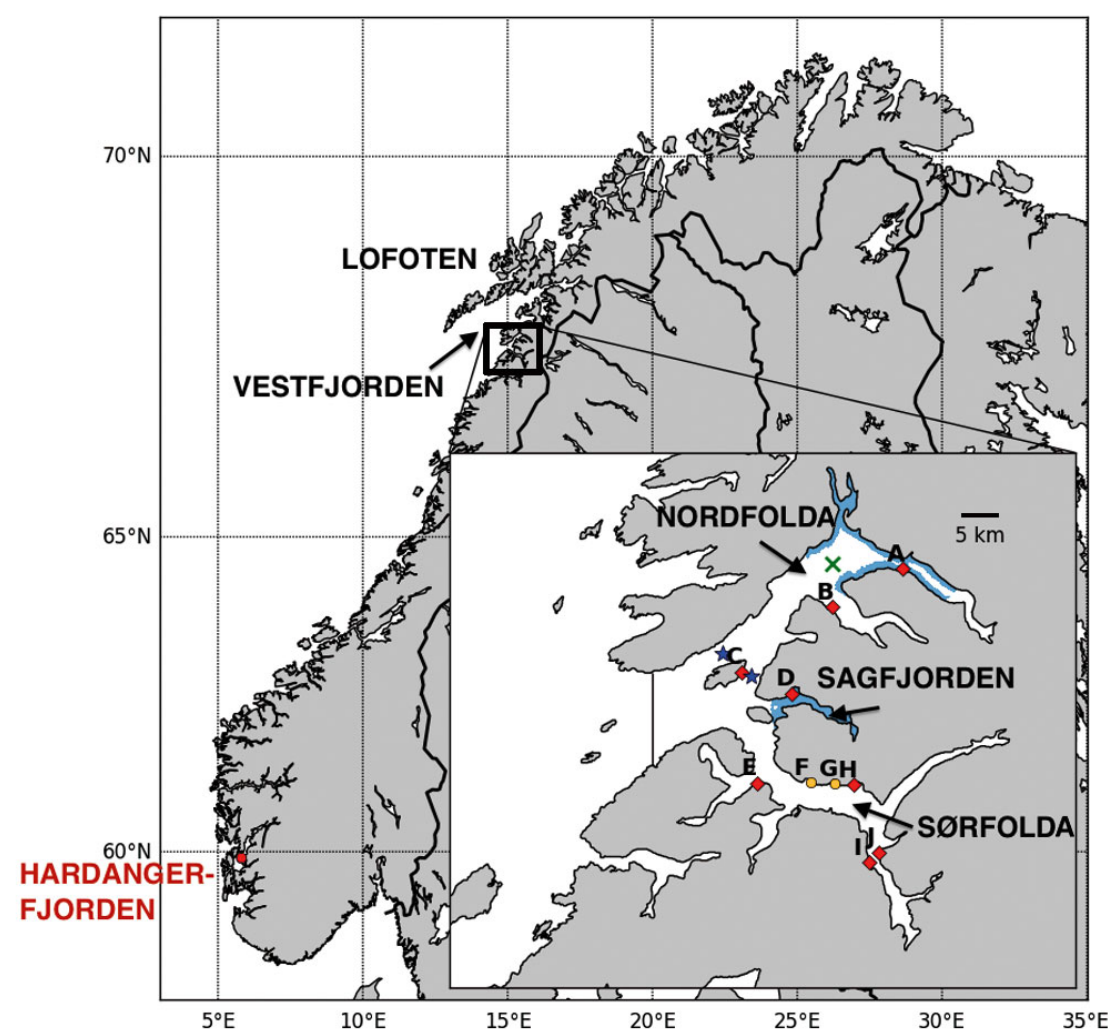

Fig. 1. The Folda fjord system on the northern coast of Norway. Red marks: active salmon farms; orange marks: fish farms not in production during the simulated period. Vertical profiles of temperature and salinity were measured at the locations indicated by the blue stars ( 7 March and 21 July 2010). Blue areas indicate the assumed residence areas for wild sea trout. The black line at the fjord mouth indicate the outer limit of calculated salmon lice retention. The green cross shows the position of buoy measuring current and salinity at $3 \mathrm{~m}$ depth and temperature at $4 \mathrm{~m}$ depth (2 July to 30 August 2010)
From the mouth to the fjord head, the distance is $\sim 60 \mathrm{~km}$ for both branches. The fjord width varies from $1 \mathrm{~km}$ at the inner parts to several $\mathrm{km}$ at the outer parts. Folda has basins exceeding $500 \mathrm{~m}$ in depth and a sill depth of around $250 \mathrm{~m}$, preventing the horizontal exchange of water between the basins and the coastal ocean. As is typical of Norwegian fjords, the terrain surrounding Folda consists of relatively steep mountains.

Freshwater runoff from rivers, heat transfer from the atmosphere, wind, tides and internal waves control the movement of the water close to the surface. The fjord system receives $160 \mathrm{~m}^{3} \mathrm{~s}^{-1}$ (mean amount calculated between 1961 and 1990) of freshwater from rivers; most of which is released into Sørfolda (Myksvoll et al. 2011). During the simulated period for this study, the fjord received close to the $30 \mathrm{yr}$ mean runoff. The tidal amplitude is relatively large with a difference of $\sim 1-2 \mathrm{~m}$ between high and low tides. The water masses in the Vestfjorden outside the mouth of Folda are variable and dominated by eddies (Mitchelson-Jacob \& Sundby 2001).

There are 10 approved fish farm locations in the fjord. Two of the fish farms were not active during the study period, but were included in the simulations in order to evaluate the potential dispersion of salmon lice even from these locations. The fjord system contains a number of wild salmonid fish; salmon Salmo salar, sea trout Salmo trutta and Arctic charr Salvelinus alpinus, all of which could potentially be exposed to salmon lice infections.

\section{The fjord current model}

The hydrography of the fjord (i.e. current, temperature and salinity) was calculated using the Regional Ocean Modeling System (ROMS; www.myroms.org). The horizontal resolution was set to $200 \mathrm{~m}$ and the vertical resolution to 35 terrainfollowing coordinates. Results from the coastal ocean current model NorKyst800 (Albretsen 2011) were used along the open boundaries of the fjord model, updating values of salinity, temperature, currents and 
water levels hourly. The Norwegian Water Resources and Energy Directorate (NVE) provided the freshwater input for the model for 58 rivers as a daily freshwater volume flux. Atmospheric forcing consisting of surface wind and radiation was calculated by the Weather Research and Forecasting model (WRF; www.wrf-model.org) with $3 \mathrm{~km}$ horizontal resolution, updated every $3 \mathrm{~h}$. Results of the fjord current model consisted of the 3-dimensional fields of currents, salinity, temperature and turbulence stored as hourly instantaneous values. The simulation period was from 1 April to 31 August 2010.

\section{The salmon lice dispersion model}

The Lagrangian Diffusion Model (LADIM) was used to simulate the dispersion of salmon lice from the 10 farms in the fjord system. Every hour, particles were released from these 10 sources, representing salmon lice nauplii produced at those farm locations at the given times. The particles were horizontally transported by the ambient currents, but were given the ability to swim towards the surface or sink as a response to environmental factors. Age was counted in degree-days to determine the infectious stage of each particle, which was assumed to be between 50 and 150 degree-days (Asplin et al. 2004, Stien et al. 2005). The environmental factors influencing the particles' vertical positioning were light, salinity and vertical mixing. The particles' responses to light and low salinity were as given in Johnsen et al. (2014), but whereas vertical mixing was held constant in earlier models (Asplin et al. 2011, 2014, Johnsen et al. 2014), we included vertical mixing of salmon lice controlled by the simulated level of turbulence to determine if it influenced horizontal dispersion. The turbulent vertical mixing in Norwegian fjords depends on the wind-driven current, tides, stratification and the shape of the fjord (Stigebrandt \& Aure 1989), and generally decreases with distance to the source (typically the surface or bottom). The implementation of dynamic turbulence was assumed to give a more realistic dispersion of salmon lice. The simulated diffusion coefficient from the fjord current model was used for calculating the turbulent vertical movement according to Visser (1997). We assumed that salmon lice stopped swimming upwards when their turbulent movements exceeded a given swimming velocity. Therefore, simulated salmon lice exposed to turbulent vertical displacement greater than $5 \times 10^{-4} \mathrm{~m}$ $\mathrm{s}^{-1}$ were set to sink with a vertical velocity of $10^{-3} \mathrm{~m}$ $\mathrm{s}^{-1}$ (Bricknell et al. 2006) until less turbulent conditions were reached. Turbulence levels exceeding $0.1 \mathrm{~m}^{2} \mathrm{~s}^{-1}$ were assumed to be numerical miscalculations and were set to $0.1 \mathrm{~m}^{2} \mathrm{~s}^{-1}$.

\section{Sensitivity parameters tested}

To test the sensitivity of the vertical distribution (and hence horizontal dispersion) of salmon lice to environmental factors we performed 6 simulations, varying the following parameters: (1) the lightsensing level of the lice, (2) level of surface light, (3) vertical mixing of the lice, and (4) swimming velocity of the lice. Various model parameterizations for the sensitivity experiment are provided in Table 1. Salmon lice are known to be positively phototactic (Bron et al. 1993, Heuch et al. 1995, Gravil 1996, Flamarique et al. 2000). The light levels assumed to trigger lice to swim vertically in the simulations

Table 1. Parameter settings used for triggering vertical swimming during the salmon lice Lepeophtheirus salmonis simulation

\begin{tabular}{|c|c|c|c|c|}
\hline Parameter & $\begin{array}{l}\text { Light sensitivity } \\
\left(\mu \mathrm{mol} \text { photons } \mathrm{s}^{-1} \mathrm{~m}^{-2}\right)\end{array}$ & $\begin{array}{l}\text { Surface light } \\
\left(\mu \mathrm{mol} \text { photons } \mathrm{s}^{-1} \mathrm{~m}^{-2}\right)\end{array}$ & $\begin{array}{l}\text { Vertical mixing } \\
\left(\mathrm{m}^{2} \mathrm{~s}^{-1}\right)\end{array}$ & $\begin{array}{l}\text { Vertical swimming } \\
\text { velocity }\left(\mathrm{m} \mathrm{s}^{-1}\right)\end{array}$ \\
\hline Random walk & $\begin{array}{l}\text { Nauplii: } 0.3 \\
\text { Copepodids: } 2.06 \times 10^{-5}\end{array}$ & $\begin{array}{l}\text { Calculated at actual } \\
\text { position }\end{array}$ & $\begin{array}{l}\text { Constant: } \\
D=10^{-3}\end{array}$ & $5 \times 10^{-4}$ \\
\hline Dynamic mixing & $\begin{array}{l}\text { Nauplii: } 0.3 \\
\text { Copepodids: } 2.06 \times 10^{-5}\end{array}$ & $\begin{array}{l}\text { Calculated at actual } \\
\text { position }\end{array}$ & $\begin{array}{l}\text { Dynamic: from } \\
\text { fjord model }\end{array}$ & $5 \times 10^{-4}$ \\
\hline Less light sensitive & All stages: 0.1 & $\begin{array}{l}\text { Calculated at actual } \\
\text { position }\end{array}$ & $\begin{array}{l}\text { Dynamic: from } \\
\text { fjord model }\end{array}$ & $5 \times 10^{-4}$ \\
\hline $60^{\circ} \mathrm{N}$-light & $\begin{array}{l}\text { Nauplii: } 0.3 \\
\text { Copepodids: } 2.06 \times 10^{-5}\end{array}$ & Calculated for $60^{\circ} \mathrm{N}$ & $\begin{array}{l}\text { Dynamic: from } \\
\text { fjord model }\end{array}$ & $5 \times 10^{-4}$ \\
\hline Slow swimmers & $\begin{array}{l}\text { Nauplii: } 0.3 \\
\text { Copepodids: } 2.06 \times 10^{-5}\end{array}$ & $\begin{array}{l}\text { Calculated at actual } \\
\text { position }\end{array}$ & $\begin{array}{l}\text { Dynamic: from } \\
\text { fjord model }\end{array}$ & $10^{-4}$ \\
\hline Fast swimmers & $\begin{array}{l}\text { Nauplii: } 0.3 \\
\text { Copepodids: } 2.06 \times 10^{-5}\end{array}$ & $\begin{array}{l}\text { Calculated at actual } \\
\text { position }\end{array}$ & $\begin{array}{l}\text { Dynamic: from } \\
\text { fjord model }\end{array}$ & $10^{-3}$ \\
\hline
\end{tabular}


'random walk', 'dynamic mixing', ' $60^{\circ} \mathrm{N}$-light', 'slow swimmers' and 'fast swimmers' were selected based on Flamarique et al. (2000). Salmon lice are also known to exhibit burst swimming (Gravil 1996, Heuch \& Karlsen 1997). As the swimming bursts occur on a smaller time scale than the temporal resolution of the model, we assumed that burst swimming episodes could be represented by a mean swimming velocity of ca. 1 body length $\mathrm{s}^{-1}$. Surface light was calculated by latitude and time of day according to Skartveit \& Olseth (1988); see Johnsen et al. (2014) for details. In addition, the simulated distribution was plotted with and without calculated mortality, to investigate the impact of mortality on the distribution of the lice.

Simulations were run with an equal release of salmon lice from all farms to test potential connectivity between the farms, but also with a realistic release of salmon lice calculated from observed infestation levels at the farm sites. All fish farms in Norway are obligated to monitor the amount of salmon lice on their fish. In 2010, the number of lice per fish was counted monthly on all farms in the area and reported to the authorities. The number of adult female lice per fish was made available to us, along with the number of fish and the measured seawater temperature at $3 \mathrm{~m}$ depth from all locations. We assumed that the lice counting was performed on the first day every month, and that the adult females were continuously producing eggs in 2 egg strings, with each string containing 150 eggs (Jackson \& Minchin 1993). The estimated release of salmon lice nauplii from each location was based on the formula described in Stien et al. (2005), i.e. a daily production of $25 \mathrm{ind}$. female ${ }^{-1}$ $\mathrm{d}^{-1}$ at $10^{\circ} \mathrm{C}$. The number of eggs was linearly interpolated to daily values.

\section{Observed hydrography and currents}

Vertical salinity and temperature profiles were obtained on 7 March and 21 July 2010 for the positions marked by blue stars in Fig. 1 and compared to the model results as validation. We used the CTD-sonde SAIV SD204 (www.saivas.no) with a 1 s sampling interval.

An observation buoy located in Nordfolda (Fig. 1, green cross) measured salinity and temperature at 4 and $10 \mathrm{~m}$ depths, and current at $3 \mathrm{~m}$ depth from 1 July to 30 August 2010. Salinity and temperature were measured using conductivity sensor number 3019 from Aanderaa Instruments (www.aadi.no) with a $2 \mathrm{~s}$ sampling interval. Current measurements were made with an Aanderaa Instruments Doppler current sensor DCS4100 (www.aadi.no), measuring flow close to the sensor with a $1 \mathrm{~s}$ sampling interval.

\section{Salmon lice infestation on wild fish}

Sea trout were caught at 2 locations (Sagfjorden and Nordfolda; Fig. 1) using floating gill nets following the methods described in Serra-Llinares et al. (2014). Lice stages (copepodid/chalimi, pre-adult, adult) were identified on a morphological basis according to Johnson \& Albright (1991) and Schram (1993). Only newly attached salmon lice (copepodid and chalimus stages) were used in this paper. This data was previously published in a MSc thesis (Svedberg 2011).

\section{Comparing simulated densities of salmon lice to observed salmon lice infections}

In order to compare the simulated salmon lice density with observations on wild fish, we defined a potential infection area around the observation site as being within $7 \mathrm{~km}$ of all river mouths and $200 \mathrm{~m}$ from land, indicated by the blue areas in Fig. 1. We assumed that the infestations of lice occurred within $20 \mathrm{~d}$ prior fishing, which is the time period that is required for development to the pre-adult stage at $10-12^{\circ} \mathrm{C}$ (Stien et al. 2005). The swimming routes of the fish were not known, but we assumed that each fish would have been exposed to a fraction of the water volume within the infection area. We calculated the water volume that a fish would be exposed to during $20 \mathrm{~d}$ of swimming at a velocity of $0.15 \mathrm{~m} \mathrm{~s}^{-1}$ (Thorstad et al. 2004, 2014), assuming a lice detection range of $0.03 \mathrm{~m}$ (Heuch et al. 2007; a cylinder with $0.03 \mathrm{~m}$ radius as long as the travelled distance). Furthermore, we assumed that $10 \%$ of the lice within this volume were able to successfully attach to the fish (Tucker et al. 2000).

As the number of captured fish was low (14-24 fish), no statistical analysis was conducted.

\section{RESULTS}

\section{Fjord hydrography}

The currents and hydrography of the Folda are typical of fjords with a freshwater supply, with a mean surface current out of the fjord in the brackish 


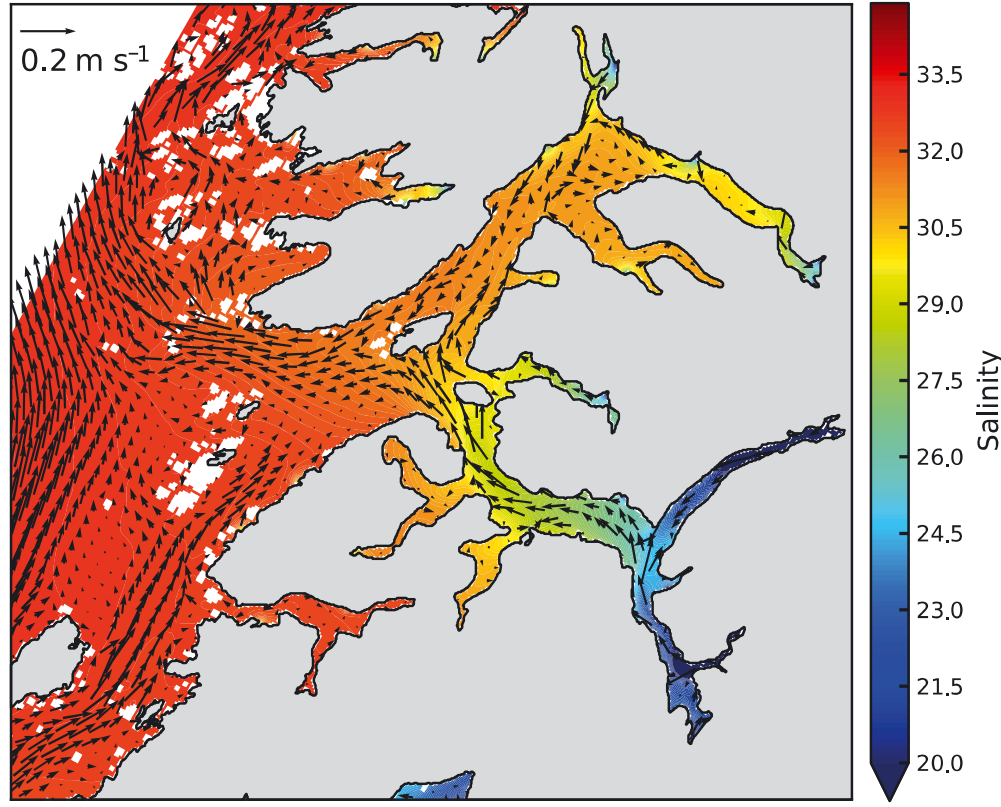

Fig. 2. Surface salinity and current vectors showing average values for the simulation period (1 April to 31 August 2010)

surface layer. In Sørfolda, where the river discharge is largest, the mean surface current was directed straight out of the fjord. Nordfolda, being a wider fjord with a lower freshwater supply, has a more complex surface circulation. On the southern side of Nordfolda the mean current is directed into the fjord, whilst a stronger outflow occurs on the western side (Fig. 2). The salmon lice in the fjord were influenced by the freshwater supply in terms of the general circulation, but also because the river discharge caused areas of low salinity water $(<20)$ which the salmon lice avoided. These low salinity areas were close to the surface (seldom lower than $2 \mathrm{~m}$ depth), but fluctuated over time. Normally the low salinity surface was within $5 \mathrm{~km}$ of the inner fjord heads, but on 25 May low salinity water was observed over the whole surface of Sørfolda. There were northwesterly winds at the coast prior to this event, which created an aggregation of low salinity water within the fjord. The low salinity surface water extended deeper than normal in the inner part of the fjord days prior to 25 May, and when the coastal wind lessened in magnitude, the low salinity water that had collected at the fjord head flushed out of Sørfolda. The situation lasted less than $1 \mathrm{~d}$.

The mean surface circulation pattern shown in Fig. 2 extended as deep as $5 \mathrm{~m}$, and decreased in magnitude with depth. At 10-30 m depth, the mean circulation was in a counter-current direction into Sørfolda, with a magnitude of $0.05 \mathrm{~m} \mathrm{~s}^{-1}$. A relatively frequent exchange of water through propagation of long internal waves between Folda and the coast with currents of $0.1-0.3 \mathrm{~m} \mathrm{~s}^{-1}$ occurred irregularly (about every $14 \mathrm{~d}$ ), and lasted 3-7 d. The water exchange between the fjord system and the coastal water correlates with the wind at the coast (Fig. 3). The currents outside the fjord were mainly directed parallel to the coast $\left(\sim 45^{\circ}\right.$ compass direction). The southwesterly wind transported water into the fjord while the northeasterly wind transported water out of the fjord. Currents directed out of the fjord affected a shallower part of the surface layer than the inflowing current (Fig. 3), indicating that water transport out of the fjord is generated by wind stress at the surface and is restricted to the low-salinity water close to the surface, whereas inflow occurs as a result of density-driven waves propagating into the fjord as described in Asplin et al. (1999). The inflowing water passed the fjord mouth and entered both Sørfolda and Nordfolda. In Nordfolda, the inflowing water followed the east side of the fjord, and subsequently generated an outflow at the western side of the fjord (Fig. 3). The tides have an amplitude of 1 to $2 \mathrm{~m}$ in the area, but since the fjord is both relatively wide and deep, the resulting tidal current speed was limited $\left(0.05 \mathrm{~m} \mathrm{~s}^{-1}\right)$.

\section{Fjord model validation}

The observed salinity and temperature profiles showed increased stratification in the fjord from 7 May to 21 June. In the beginning of May, the water was well-mixed at $5^{\circ} \mathrm{C}$ and a salinity of $32-34$. In June, the temperature had increased to $11-12^{\circ} \mathrm{C}$ at the surface, decreasing with depth to $9^{\circ} \mathrm{C}$ at $30 \mathrm{~m}$. This stratification was a result of absorbed solar radiation, heat flux from the atmosphere and river runoff. The model recreated the stratification well in the top $10 \mathrm{~m}$ of the water column, but at $10-30 \mathrm{~m}$ depth the modelled water temperature was up to $1^{\circ} \mathrm{C}$ colder than the observed temperature. At the buoy position in Nordfolda, the simulated and observed temperatures followed each other in time, with the model on average underestimating the temperature at $4 \mathrm{~m}$ depth by $0.5^{\circ} \mathrm{C}$, and overestimating the temperature by $<0.1^{\circ} \mathrm{C}$ at $10 \mathrm{~m}$ depth. The observed salinity was always at the lower range of the simulated salinity, but the model never deviated from the observed salin- 

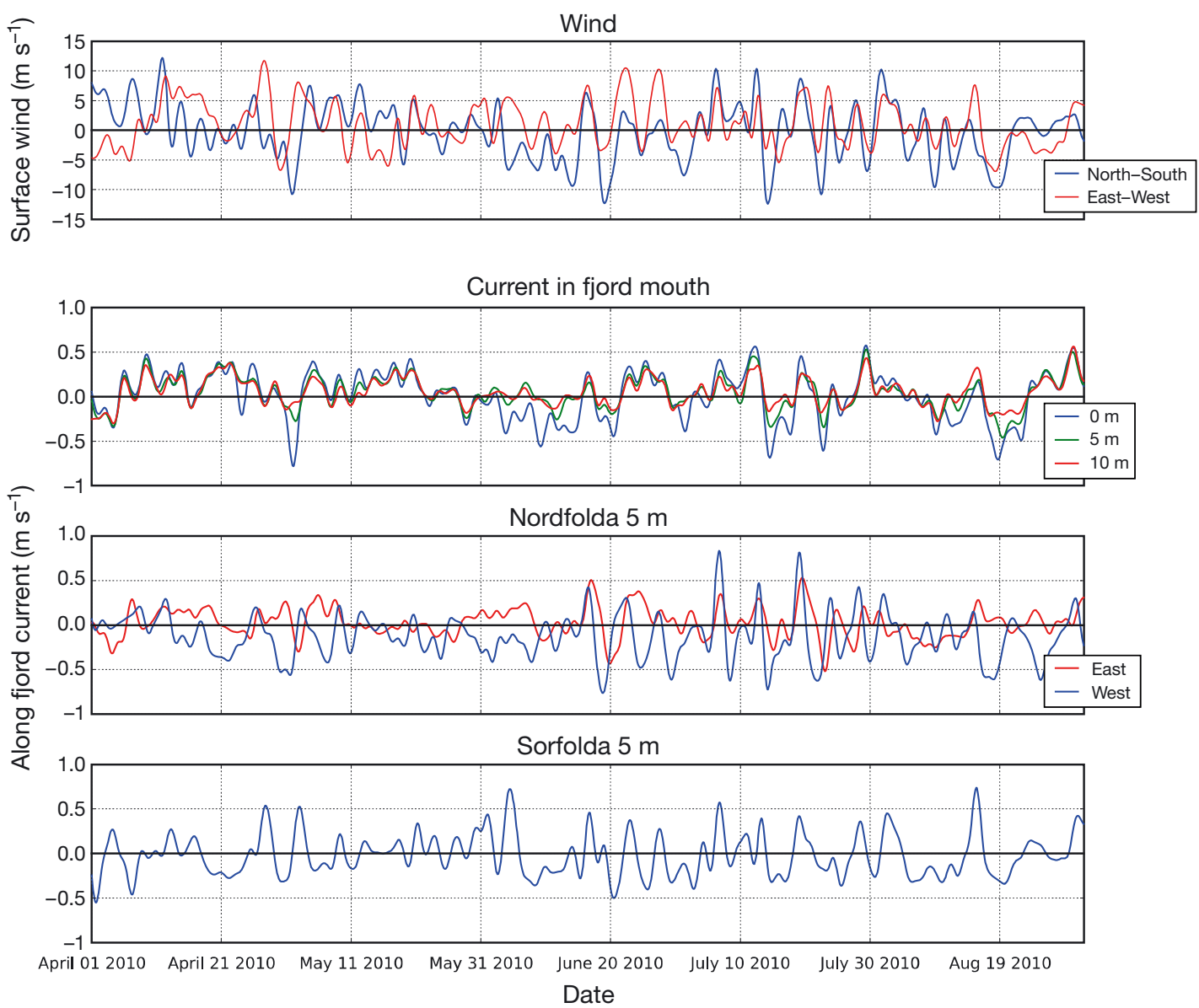

Fig. 3. Simulated surface wind at Vestfjorden outside the Folda fjord system and along fjord current in the middle of the mouth of Folda (0, 5 and $10 \mathrm{~m}$ depth, compass direction $60^{\circ}$ ), Nordfolda (east and west side, $5 \mathrm{~m}$, compass direction $45^{\circ}$ ) and Sørfolda $\left(5 \mathrm{~m}\right.$, compass direction $\left.135^{\circ}\right)$. Positive currents are directed into the fjord

ity by more than 1 unit. The hourly model results revealed relatively large variations in temperature and salinity over the course of a day. These fluctuations were the result of tidal movements of the water masses and were largest close to the surface. The temperature fluctuations were most obvious close to the fjord mouth and increased with the fjord temperature during spring. In June, tidal temperature fluctuations were typically around $2{ }^{\circ} \mathrm{C}$ at the surface close to the fjord mouth due to the tidal movement of water masses with a horizontal temperature gradient between the fjord- and coastal water. At the inner parts of the fjord where the salinity gradient is strongest, the fluctuation in salinity within a day was often up to 4 salinity units. Even though the model underestimated the vertical temperature and salinity gradient it was able to reproduce the currents close to that of the observations (Fig. 4). The measured current was directed into the fjord $41 \%$ of the time with a mean velocity of $0.09 \mathrm{~m} \mathrm{~s}^{-1}$, and the mean velocity directed out of the fjord was $0.08 \mathrm{~m} \mathrm{~s}^{-1}$. The fjord model pre- dicted currents at the corresponding position to be directed into the fjord $51 \%$ of the time with a magnitude of $0.11 \mathrm{~m} \mathrm{~s}^{-1}$. The modelled mean velocity out of the fjord was $0.07 \mathrm{~m} \mathrm{~s}^{-1}$. Over the full simulation period, the model slightly overestimated the currents into the fjord compared to the field observations.

\section{Sensitivity of the salmon lice dispersion model}

In the model, the vertical distribution of salmon lice (and hence horizontal dispersion since the horizontal current varied with depth) was affected by the parameterization of lice behaviour (Fig. 5). The largest distribution difference occurred by changing the lice's swimming velocity. When the simulated lice were given a vertical swimming capacity of $10^{-4} \mathrm{~m} \mathrm{~s}^{-1}$ (i.e. slow swimmers), they were not able to aggregate as close to the surface as they were by increasing the swimming velocity. A difference in swimming velocity between $10^{-3} \mathrm{~m} \mathrm{~s}^{-1}$ (dynamic mixing) and $5 \times$ 

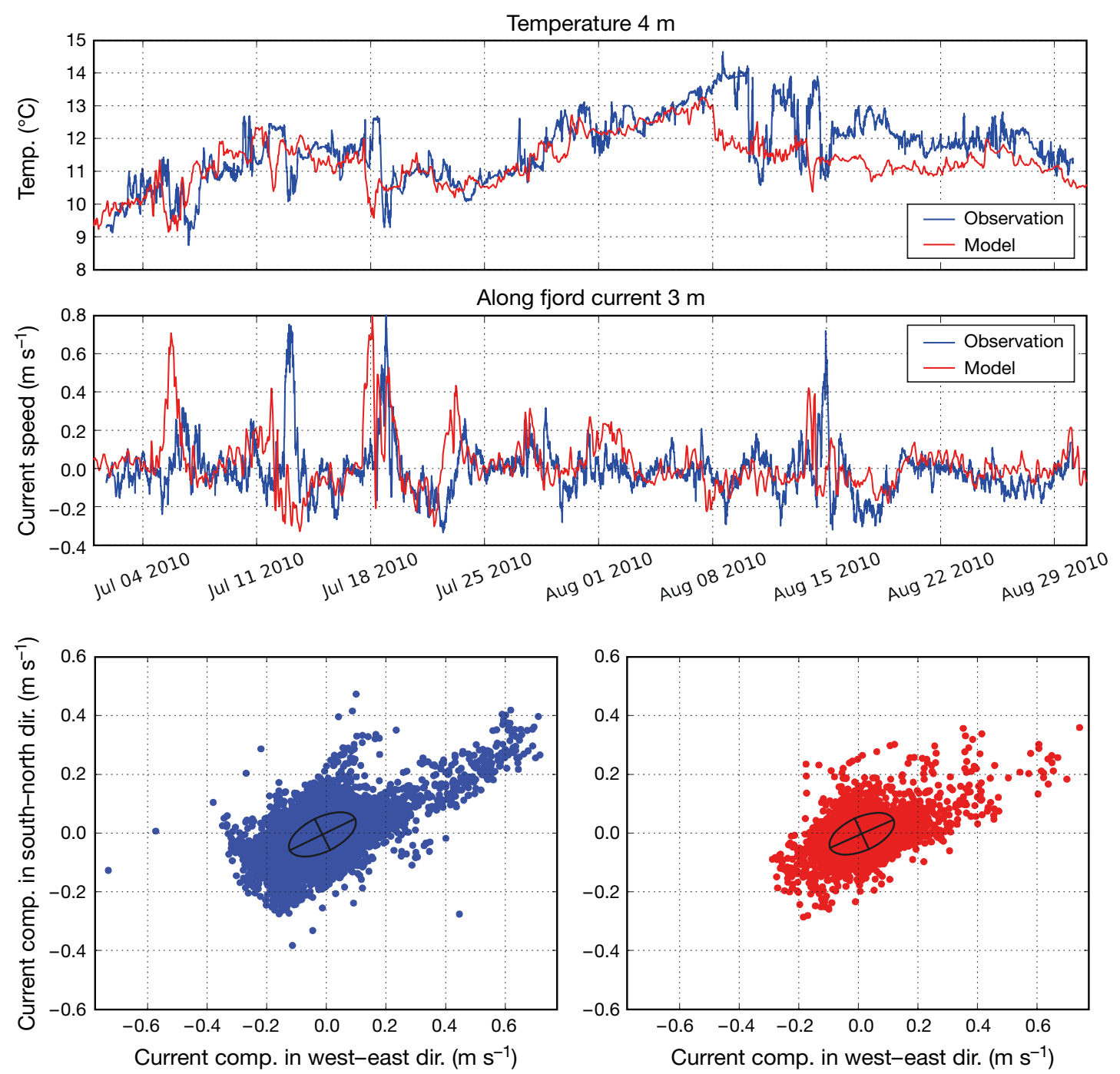

Fig. 4. Observed and simulated temperatures (top panel) and current in Nordfolda (green cross in Fig. 1). Along fjord current with positive current heading into the fjord (middle panel) and scatterplots of the velocity, with ellipse marking the standard deviation along and across the main current direction (lower panels). Observed data in blue, simulated data at the corresponding location in red

$10^{-3} \mathrm{~m} \mathrm{~s}^{-1}$ (fast swimmers) altered the vertical distribution only to a small degree. As the simulated lice were reflected at the surface, a further increase in swimming velocity did not increase the number of salmon lice at the surface. By decreasing the light sensitivity of the lice to $0.1 \mu \mathrm{mol}$ photons $\mathrm{s}^{-1} \mathrm{~m}^{-2}$ (i.e. less light sensitive), the vertical distribution was altered only to a minor extent. The irradiance level at the position of the salmon lice exceeded $0.1 \mu \mathrm{mol}$ photons $\mathrm{s}^{-1} \mathrm{~m}^{-2}$ most of the day, triggering them to swim upwards. Simulations run using light levels similar to those in southern Norway at $60.0^{\circ} \mathrm{N}\left(60^{\circ} \mathrm{N}\right.$ light) with shorter days but similar light intensity at mid-day did not give results that differed from the simulation with light levels calculated from the actual position (i.e. dynamic mixing).
The simulated turbulence in the fjord was greater in Nordfolda than in Sørfolda. However, overall the water was less turbulent inside the fjord system than in the earlier assumptions in which the vertical mixing was set by random walk and limited by a constant diffusion coefficient of $10^{-3} \mathrm{~m}^{2} \mathrm{~s}^{-1}$ (Asplin et al. 2014, Johnsen et al. 2014). On the other hand, this constant value was often exceeded at the coast outside the fjord. Depending on the driving forces, the turbulence level varied from close to zero to $0.1 \mathrm{~m}^{2} \mathrm{~s}^{-1}$. The vertical lice distribution fluctuated more in time by modifying the model from the assumption of constant turbulent mixing in the vertical (random walk), in which the salmon lice swam up during the day and dispersed in the vertical during the night, to using the instant vertical mixing parameter as simulated by 


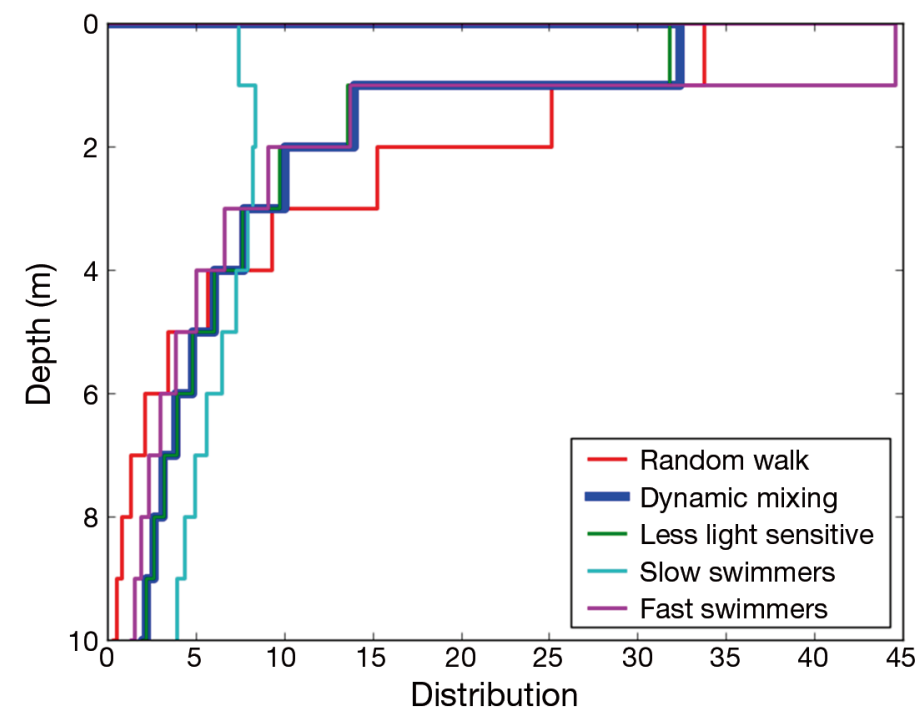

Fig. 5. Aggregated vertical distribution of salmon lice Lepeophtheirus salmonis copepodids during simulations from all farms with parameters as defined in Table 1

the current model (dynamic mixing). When the salmon lice experienced greater displacement from vertical mixing than they were able to overcome with their swimming capacity, the they sank down to avoid the high turbulence. Thus the mean distribution of salmon lice was deeper for the dynamic mixing simulation compared to the random walk simulation (Fig. 6).

The total horizontal area affected by the dispersed salmon lice from all fish farms in the fjord ranged between 3780 and $4190 \mathrm{~km}^{2}$, depending on the simulated vertical behaviour of the lice (mortality included). In total, $95 \%$ of infectious lice were found within $25 \%$ of the total influenced area. The largest influence area occurred with the random walk simulation, while the slow swimmers simulation displayed the smallest area.

The retention of salmon lice within the fjord system was defined as the fraction of infectious salmon lice residing inside the fjord mouth (indicated by the line in Fig. 1). The time-averaged retention between the simulations was $82-86 \%$. The random walk simulation had the greatest retention while the slow swimmers simulation had the smallest. Retention fluctuated over time with the exchange of water into and out of the fjord. Salmon lice retention varied over time between 60 to $>95 \%$ for the dynamic mixing simulation. As the simulated salmon lice sank when turbulent mixing exceeded their vertical swimming capacity, the lice were distributed deeper during periods with increased mixing. Nordfolda was more exposed to vertical mixing than Sørfolda, and hence the vertical distribution was deeper there. Turbulence was strongest during inflow episodes to the fjord system, and therefore the salmon lice were distributed deeper during inflow than outflow, and were unable to increase their retention within the fjord by sinking down at times with large vertical mixing.

The time-averaged aggregation of infectious copepodids along land was $28-29 \%$ for all of the simulations, but large fluctuations in time also occurred here. The dynamic mixing simulation results showed more salmon lice residing mid-fjord in Nordfolda than the other simulation results. In the following
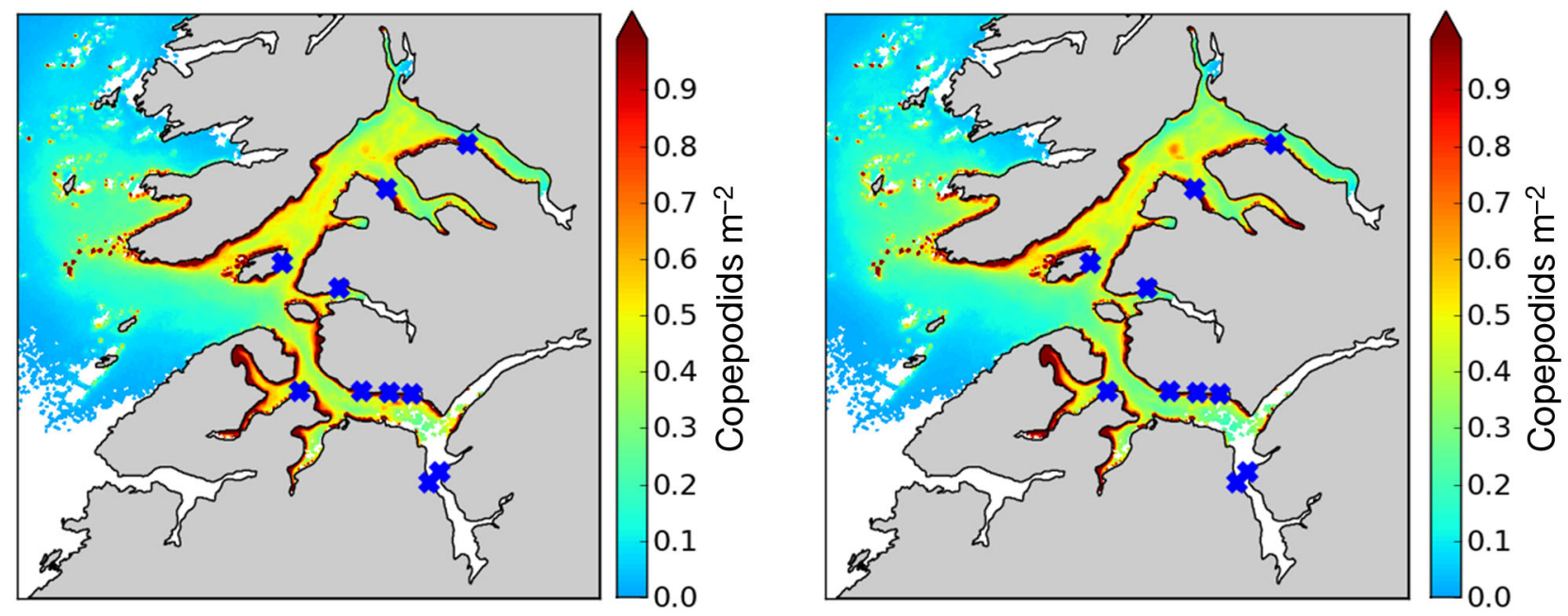

Fig. 6. Normalized horizontal distribution of salmon lice Lepeophtheirus salmonis copepodids from simulation with no mortality (right) and mortality of $0.17 \% \mathrm{~d}^{-1}$ (left) during nauplii and copepodid stages. All sources release the same number of particles 
section, the presented model results are from the dynamic mixing parameterization.

By including a constant mortality of 0.17 ind. $\mathrm{d}^{-1}$, $35 \%$ of the salmon lice reached the copepodid stage. Survival to copepodid stage is dependent on temperature, but was the same as reported for Hardangerfjord in May 2009 (Johnsen et al. 2014). Mortality during the planktonic stages (both nauplii and copepodid) decreased the density field of infectious copepodids to $14 \%$ of the simulation with no mortality (1 April to 31 August 2010). However, by normalizing the density fields it became apparent that the distributions were qualitatively almost identical (Fig. 6).

\section{Salmon lice distribution and validation}

The salmon lice simulation was conducted using the dynamic mixing parameterization, including mortality, for the time period 1 April to 31 August 2010, releasing realistic numbers of lice from all active farms in the region. During the summer, the model predicted lice to be present in the whole fjord system. The distribution of lice fluctuated widely both in time and space, but as a general feature the largest densities of infectious lice occurred inside the fjord, with an aggregation along land (Fig. 7). The land aggregation was most pronounced in Sørfolda. The number of salmon lice copepdids residing within the same area as the captured sea trout was also highly variable in time (Fig. 8). The

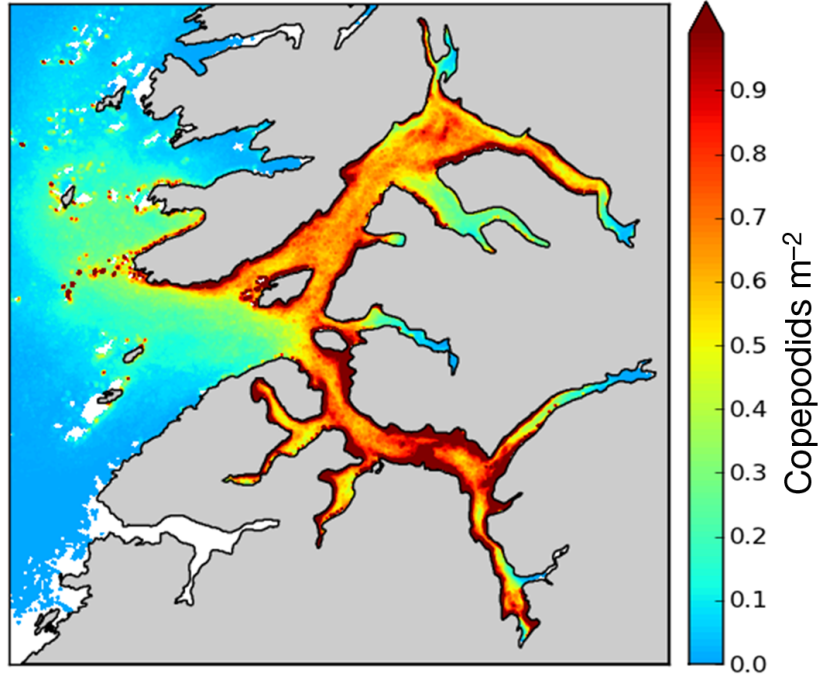

Fig. 7. Mean density of salmon lice Lepeophtheirus salmonis released from fish farms from 1 April to 31 August 2010. The released number of salmon lice was based on the reported number of lice on all farms in the fjord system

periods assumed to correspond to the infestation of the wild fish are marked with grey in Fig. 8. The observed number of lice on wild fish was greatest in Norfolda during Week 29. There was a good agreement between the modelled salmon lice infestation and the number of lice observed on the wild fish, with the exception of Week 26, where the model overestimated the number of lice in Nordfolda (Fig. 9).

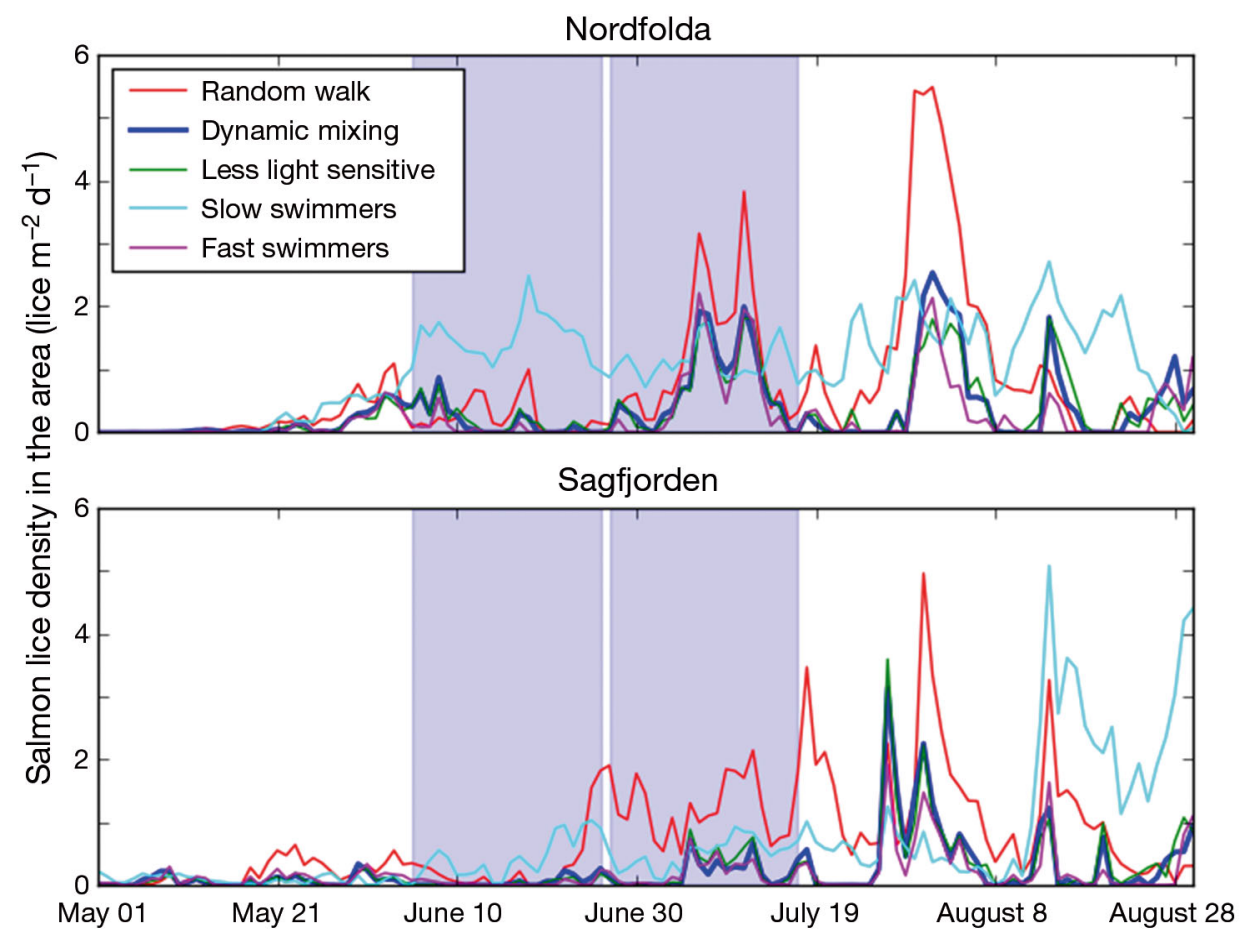

Fig. 8. Simulated density of salmon lice Lepeophtheirus salmonis copepodids residing within the blue area in Fig. 1. Shaded area: assumed infection time for the captured wild fish 


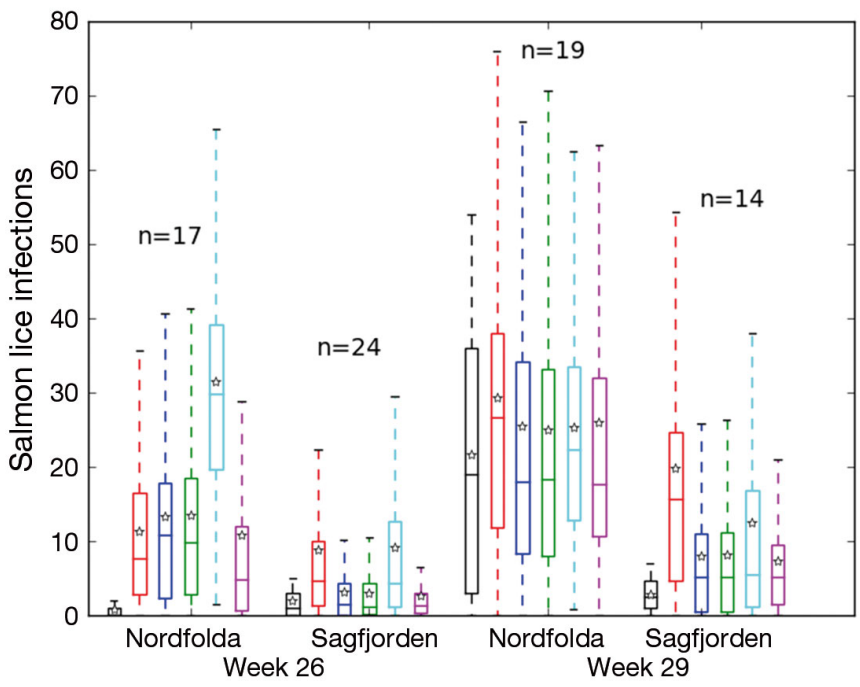

Fig. 9. Observed (black box) and simulated (coloured boxes, colour codes as in Fig. 8) salmon lice Lepeophtheirus salmonis infections on wild sea trout Salmo trutta ( $=$ no. of fish). Note that the boxes show the $25^{\text {th }}$ and $75^{\text {th }}$ percentiles for the variation in infestation for the observations, and variation between the horizontal grids for the model; whiskers show extremes

\section{Potential dispersion of lice}

The simulated abundance of salmon lice in Folda was greatly affected by the production cycles on the different farms, in which those farms containing many large fish released more lice into the fjords than the ones having smaller (or less) fish. In order to evaluate the potential dispersion between farms on a general basis, simulations were re-run with the condition that all farms released the same amount of salmon lice. In the following analysis, the dynamic mixing simulation was used and mortality was included. By simulating the release of the same amount of salmon lice it became clear that the farms in Nordfolda were more exposed to lice originating from farms in Sørfolda than the other way around. The reason for this difference was that the currents transported more water from Sørfolda into Nordfolda than vice versa (Fig. 10).

By the time the salmon lice reached the infectious copepodid stage, they had been transported away from their release positions. In total, 20 and $24 \%$ of the lice released from Farms $\mathrm{C}$ and $\mathrm{E}$ (see Fig. 1) were found $<10 \mathrm{~km}$ from their initial release position. For the remaining farms, the number never exceeded $6 \%$. In general, salmon lice released close to the head of the fjord were transported furthest away, whereas those released closer to the mouth created an infection pressure that covered a larger area (Fig. 11). This is a result of the fjords being narrower

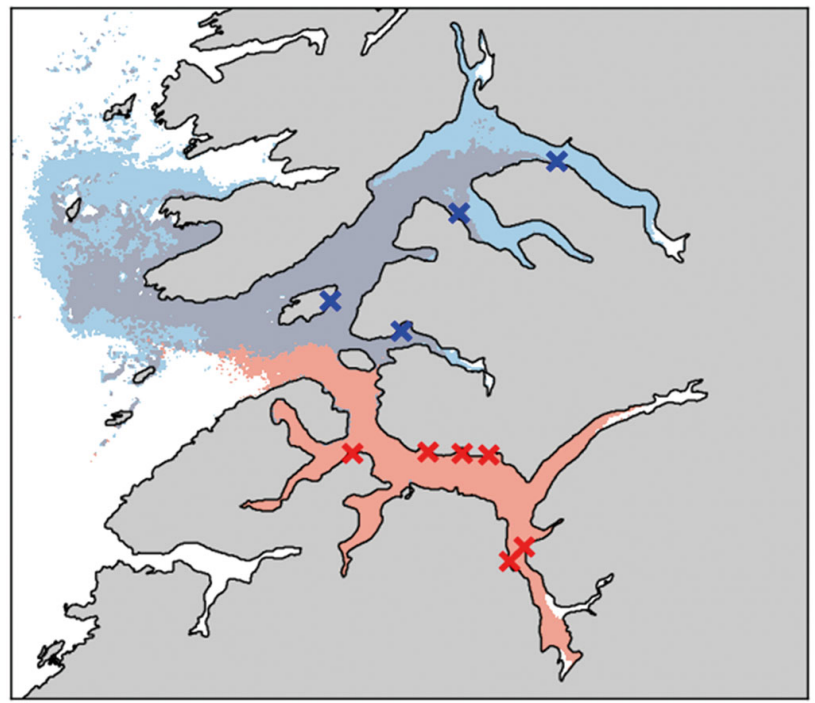

Fig. 10. Area influenced by $85 \%$ of the largest densities of infectious salmon lice Lepeophtheirus salmonis released by farms (crosses) in Nordfolda (blue) and Sørfolda (red, grey if overlapping with blue). Area calculation is based on abundance date re-run by the dynamic mixing simulation, with mortality included and assuming all farms released the same amount of salmon lice

closer to the head. The area in which salmon lice can disperse is more restricted close to the fjord head than in the more open parts of the fjord. Currents generated by tides, wind and density differences are directed along the fjord in the inner region, efficiently transporting the lice away from their source.

\section{Connectivity between the farms}

In order to evaluate connectivity between the salmon farms in terms of export and import of salmon lice, all copepodids entering a $3 \times 3$ model grid $(600 \times$ $600 \mathrm{~m}$ ) at each farm were counted. The fraction of all released lice that reached a farm during the copepodid stage was assumed to represent a potential infection. The number of potential infections was calculated between all farms and is presented in a connectivity matrix (Fig. 12). The sum of the columns in the matrix (given in Table 2) can be read as the lice exposure the farm experienced, and likewise the sum of the rows of the matrix indicates the potential infectivity from that farm (Table 2). Based on this, Farm G was most exposed to salmon lice from the other farms, and the lice from Farm $\mathrm{H}$ were most likely to find a host fish at a farm location within the fjord. The colour of the boxes along the diagonal marks the farms' potential internal infection, which 


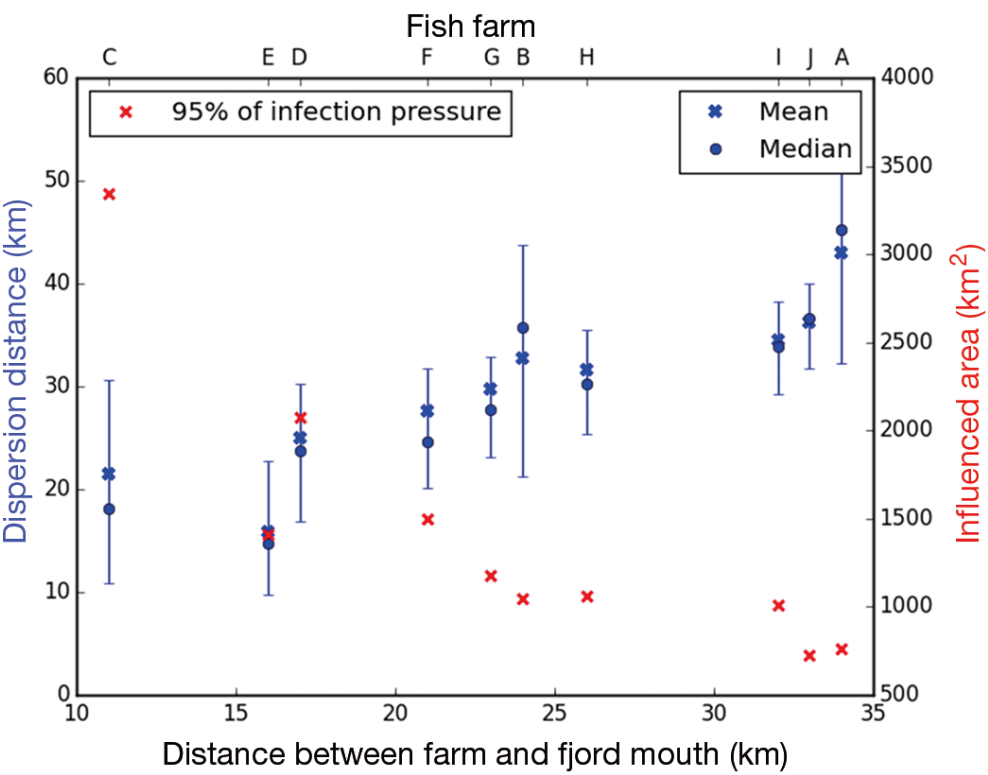

Fig. 11. Blue markers show mean and median dispersion distances of infectious salmon lice Lepeophtheirus salmonis. Blue error bars: $25^{\text {th }}$ and $75^{\text {th }}$ percentiles. Red crosses: the area in which $95 \%$ of the infection pressure occurs

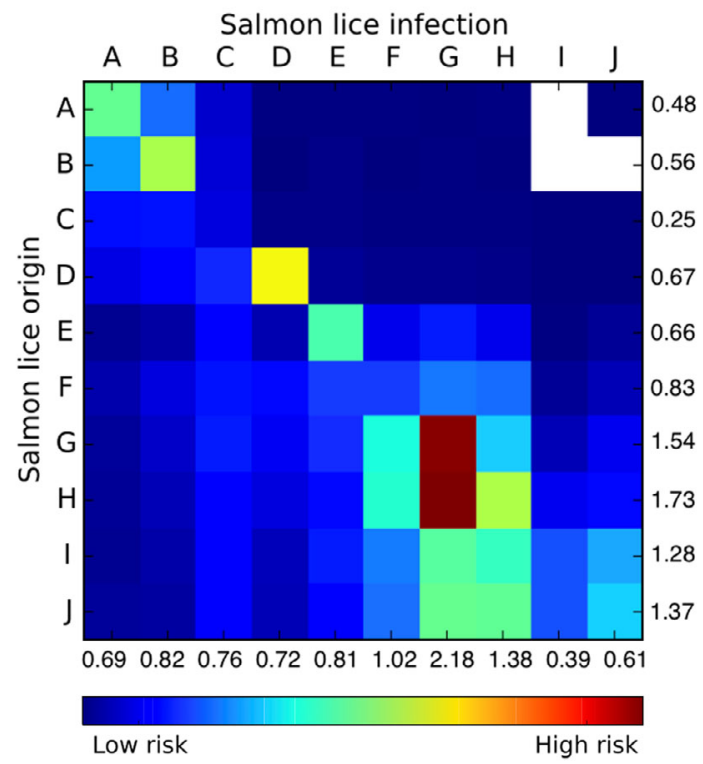

Fig. 12. Connectivity matrix of simulated salmon lice Lepeophtheirus salmonis infestation between fish farms in the Folda fjord system between 1 April and 31 August 2010 was 7 to $57 \%$ of the total potential infection (on average $32 \%$ ). Farm D was the only site that exhibited a larger internal than external infection (Table 2). The farms in Sørfolda (Farms E-J) displayed stronger connectivity than those in Nordfolda.

\section{DISCUSSION}

\section{Fjord circulation}

The fjord model was able to recreate the circulation in the fjords realistically, based on comparisons with field observations (Fig. 4). This has also been shown earlier for the Hardanger fjord (Johnsen et al. 2014). Currents are formed by contributions from wind, tides, freshwater runoff and internal waves (horizontal pressure) of remote origin. For transportation of salmon lice over longer distances, the relatively long-lasting current components are most efficient and the currents associated with internal waves are important (Asplin et al. 1999, 2014). Internal waves propagate with land on the right side on the way into the fjords, and with the upper layer current both into and out of the fjord depending on whether the internal wave is at a depressed or elevated phase (Asplin et al. 1999). In Sørfolda, the waves cover the full width of the fjord, while in the wider Nordfolda they generate stronger currents along land, thus acting as a retention eddy. As a result, salmon lice in Sørfolda aggregated along land, while in the wider Nordfolda high densities of lice were also found in the centre of the fjord. The inflow episodes were externally generated by northerly winds outside the fjord or by density differences between the fjord and the coastal water masses, demonstrating the importance of realistic boundary conditions (both surface wind and the open boundary) when simulating fjord circulations. We did not find any systematic differences in circulation dynamics in this northern Norwegian fjord compared to fjords in southern Norway.

\section{Sensitivity analysis of salmon lice dispersion}

By simulating the dispersion of salmon lice we can estimate lice densities over larger areas. If the connection between lice abundance in the water masses and lice infestations on fish is known, we can also predict the infestation pressure on wild fish. Although the model is already useful, the entire model system (including the behaviour of the planktonic lice) can still be improved. To evaluate which of the parameters had the strongest influence on the results, a sensitivity analysis evaluating different lice behaviours was conducted. Salmon lice are known to 
Table 2. Simulated potential infection, potential export and ratio internal:external salmon lice Lepeophtheirus salmonis infection for the Folda fjord system, 1 April to 31 August 2010. A-J: fish farms; see Fig. 1 for locations

\begin{tabular}{|c|c|c|c|c|c|c|c|c|c|c|}
\hline & $\mathrm{A}$ & B & $\mathrm{C}$ & $\mathrm{D}$ & $\mathrm{E}$ & $\mathrm{F}$ & G & $\mathrm{H}$ & I & $\mathrm{J}$ \\
\hline $\begin{array}{l}\text { Potential infections } \\
\left(10^{-3} \text { of all simulated lice }\right)\end{array}$ & 0.69 & 0.82 & 0.76 & 0.72 & 0.81 & 1.02 & 2.18 & 1.38 & 0.39 & 0.61 \\
\hline $\begin{array}{l}\text { Potential export } \\
\left(10^{-3} \text { of all simulated lice }\right)\end{array}$ & 0.48 & 0.56 & 0.25 & 0.67 & 0.66 & 0.83 & 1.54 & 1.73 & 1.28 & 1.37 \\
\hline Internal infection (\%) & 42 & 42 & 7 & 57 & 35 & 12 & 30 & 26 & 35 & 35 \\
\hline
\end{tabular}

be positively phototactic and can sense light at a very low level (Bron et al. 1993, Heuch et al. 1995, Gravil 1996, Flamarique et al. 2000). To the human eye, the light difference between the northern and southern Norwegian summer is obvious. However, for salmon lice that sense light at much lower levels, the water surface appears as bright during the night as during the day in both northern and southern Norway. The critical level at which the lice were triggered to swim towards the surface did not alter the model results. A further decrease in the light sensing level during the simulation resulted in a deeper distribution of the lice, but the highest densities of lice were always found at the surface. Different behaviours have been observed in laboratory experiments, in which salmon lice copepodids were reported to be more active than the nauplii stages (Gravil 1996), especially the late nauplii stage prior to moulting (Johannessen 1977, Pike et al. 1993). Variations in vertical distributions have also been reported in the literature. Penston et al. (2008) found more salmon lice nauplii at $5 \mathrm{~m}$ depth than at the surface, and á Norði et al. (2015) found only copepodids in a near-surface sampling. The same result was found by Gravil (1996) during the first nauplii stage, however for the second nauplii stage the situation was reversed. In our model, the only result showing fewer lice at the surface than deeper down was the simulation parameterized with slow swimming lice. This indicates that reduced swimming during the nauplii stage, not being less phototactic, might cause the deeper distribution of salmon lice nauplii found in nature. Salmon lice are known to be negatively geotactic (Gravil 1996), and therefore dispersion to unrealistic depths in simulations can be avoided by including such a response in the model.

With an exception of the slow swimming simulation, the vertical distribution of salmon lice copepodids in the model appears similar to the distribution observed in nature (based on pumping and net trawling; Gravil 1996, Hevrøy et al. 2003, Penston et al. 2004) and to the vertical infection gradient found by Hevrøy et al. (2003). Since the simulated level of tur- bulence generally decreased with depth and was lower within the fjord compared to the constant value used in earlier model simulations, the dynamic mixing simulation provides the most realistic results. This simulation gave the most dynamic vertical distribution of lice, indicating that a formulation of turbulence and vertical mixing should be included as precisely as possible. The simplification of turbulence in the vertical random walk did not alter the retention of salmon lice within the fjord or the aggregation along land dramatically for the whole study area, but the dynamic mixing simulation showed greater mid-fjord densities in Nordfolda.

In the dynamic mixing simulation, the lice were assumed to sink down and out of the highly turbulent water. It is known that other zooplankton that are approximately the same size as salmon lice sink down during windy conditions (Ellertsen et al. 1984, Lagadeuc et al. 1997, Incze et al. 2001). Zooplankton benefit from avoiding very turbulent water since the risk of encountering a predator increases with turbulence (Visser et al. 2008). However, salmon lice differ from other zooplankton as the increased encounter rate can increase the likelihood of meeting a host. Hence a level of turbulence that is unfavourable for other species might be favourable for salmon lice. It has been suggested that the salmon lice might seek turbulent water associated with high current velocities to be transported with the tidal currents (Costello 2006). In our study area, the largest turbulent episodes were associated with internal waves propagating into the fjords, but if the lice actively seek out these currents they would be transported into the fjord, where the sea trout mainly reside. Conversely, high levels of turbulence decrease the contact time between lice and fish, potentially making it difficult for the lice to detect and attach to the host. Salmon lice infestation success has been found to relate to the current velocities in a dome-shaped curve (Samsing et al. 2015). About $30 \%$ of the simulated salmon lice were found close to shore (i.e. the area in which sea trout reside and feed) during their 
infectious stage. Further research into the vertical behaviour of salmon lice and their infectivity under turbulent conditions or high currents would be of interest.

The mortality of the planktonic lice is naturally high, but exact mortality rates are unknown and hence impossible to simulate. By including constant mortality, the number of infectious copepodids in the fjord was reduced to $14 \%$ compared to the simulation with no mortality. However the geographical distribution was qualitatively unchanged. If dispersion were calculated using a unidirectional current field, the age of the salmon lice would increase with distance from the release position. As the mortality rate was held constant in time and space, the number of salmon lice would be reduced by age, and hence the density of lice would be lower further away from the release point. This is not the case due to the fluctuating nature of fjord circulation, where water transport and exchange occurs in pulses, dispersing into the fjords. Mortality is likely not constant in time and space due to the changing abundance of predators. This was not investigated here, but these effects might be important, especially on longer scales both in time (i.e. seasonal fluctuations) and distance (i.e. along the Norwegian coastline).

\section{Salmon lice dispersion in Folda}

Since the vertical distribution of salmon lice and simulated current are close to the ones found in earlier studies and similar to observations, it is reasonable to believe that the modelled distribution of salmon lice accurately depicts their actual distribution in the fjord. This is also supported by the fit between simulated and observed number of lice infestations on wild fish, despite the uncertainty of where the captured sea trout became infested (Fig. 9).

The assumed residence areas of the fish (Fig. 1) were based on the local rivers and earlier field studies on post-smolts tagged with acoustic transmitters (Finstad et al. 2005, Middlemas et al. 2009). Within fjords, post-smolts appear to prefer to remain close to shore rather than exploiting open waters within the mid-fjord areas (Thorstad et al. 2004, 2007). The mean distance to shore for post-smolts immediately following their entry into the marine environment was reported to be $125 \mathrm{~m}$ (Thorstad et al. 2004). In a study in northern Norway, results indicated that sea trout remained primarily within the inner parts of the fjord during the summer months (Rikardsen et al. 2007, Jensen et al. 2014).
The water volume to which a fish was exposed (which was used to calculate infestations from the modelled density field of salmon lice in the infection area) was calculated based on variables (such as swimming speed of the fish, infection time, infestation radii of the lice and infestation success) selected from the literature, but will probably vary with environmental conditions. For instance, the swimming speed of a salmonid fish depends on temperature as well as the size of the fish (Brett 1965, Brett \& Glass 1973, Webb et al. 1984). Similarly, salmon lice infestation success reportedly depends on temperature, salinity and swimming speed of the fish (Tucker et al. 2000, Bricknell et al. 2006, Samsing et al. 2015). The salmon lice counted at the farms were only reported once a month. Hatching time for the eggs in the model was set as a function of temperature, but the number of eggs produced per egg string was held constant. We believe that more frequent counting of the lice on the fish farms and possibly a variable number of eggs produced through the season would increase the quality of the model. Beginning in 2013, lice counting at fish farms on a weekly basis became mandatory. Salmon lice are known to produce fewer eggs on caged fish than on wild, and even fewer ( 150 eggs per egg string) if the caged fish are medically treated (Jackson $\&$ Minchin 1992). The lice also produce more eggs per egg string during winter than summer (Tully 1989, Gravil 1996, Heuch et al. 2000); however, 150 eggs per string is considered to be a reasonable estimate.

Despite limitations in terms of both data input and observations of salmon lice infestations on fish, the model appeared to capture the observed infestation pressure (Fig. 9). The dynamic mixing, less light sensitive and fast swimmers simulations fit the observations better than the random walk and slow swimmers simulations. Theoretically, they should be more realistic as their dispersion includes dynamic turbulence. However, it must be kept in mind that comprehensive model validation was not possible due to the limited wild fish dataset, as only 14-24 wild fish were collected. Since the model is generic (i.e. without any tuning of the currents or hydrography to measurements), the model should be equally suitable for the entire Norwegian coast on a similar scale.

Open water observations indicate that salmon lice infestations occur in pulses (Costelloe et al. 1995, Penston et al. 2004). Our model supports these findings, and explains these pulses as a result of moving water masses. The large concentrations along the shore indicated by the model results are supported by the findings of McKibben \& Hay (2004) and Penston et al. (2008), who reported the largest amounts 
of infectious copepodids along shorelines. As this is the area where wild salmon migrate to the sea, and where sea trout reside, it is the area where salmon lice naturally have the greatest chance of success (Pemberton 1976, Thorstad et al. 2004, 2007).

The wild fish in the Folda fjord system are influenced by the salmon lice infestations that occur at the farms in the area. On average, migrating salmon smolts were estimated to have a population reduction of 0,28 and $31 \%$ in 2010, 2011 and 2012 caused by infestations of salmon lice (Taranger et al. 2014b). The corresponding numbers for sea trout were on average 28,48 and $49 \%$ (with large geographical differences). In order to reduce the lice-induced mortality of the wild fish (especially for sea trout and charr), coordinated management of the fish farms in the area should be considered.

\section{CONCLUSIONS}

Numerical models can provide valuable and quantitative information of both spatial and temporal salmon lice dispersion, connectivity between fish farms and infestation levels of wild fish. Hence, with this model we were able to define the dispersal of salmon lice and the regional influence from specific farm locations. The models also make it possible to test different area management scenarios (i.e. production zones, disease management areas or fire breaks) in order to optimize sizes of management areas and the distance between these. In general, the lice released from farms in the Folda fjord system are efficiently transported away from their source and disperse over a large area. The median transport distance of the lice is on the same scale as that found in the Hardangerfjord, Norway (Asplin et al. 2011) and in the Broughton Arcipelago of British Columbia, Canada (Brooks 2005) but about 5 times greater than that found in Loch Torridon and Shieldag, and Loch Linnhe, Scotland (Gillibrandt \& Willis 2007, Amundrud \& Murray 2009, Salama et al. 2015). In Folda, the dispersion distance increased with distance from the fjord mouth, but the influence area decreased because the fjord area is smallest here. This illustrates the challenges involved in presenting dispersion results for management purposes. The smallest influence area might seem desirable, but it also represents the most efficient transport of lice away from the source.

Even if the fjord experiences pulses of inflowing water, the general circulation pattern transports more lice from Sørfolda to Nordfolda than vice versa. Thus delousing treatments would be most effective if they were coordinated and began in the southern part of the fjord system.

The dispersion of salmon lice over large areas leads to a rapid dilution in the water masses. Less than $1 \%$ of the simulated salmon lice came close to a salmon farm location during their infectious stage. In comparison, the simulated connectivity between farms was 10 times larger in Loch Fyne, Scotland, although the relationship of internal/external exposure was about the same (Adams et al. 2015). Differences in connectivity between farms were found, with Farm G being 3 times more exposed to lice than Farm J, while Farm $\mathrm{H}$ exported almost 7 times more lice to the other farms than Farm C. Despite less than $6 \%$ of the infectious salmon lice eventually residing $<10 \mathrm{~km}$ from their release positions, 6 out of 10 farms had greater internal exposure than exposure from any other single farm. However, external exposure must be counted as the sum of exposure from all other farms; when calculating the ratio between internal exposure and the sum of exposure from all other farms only Farm D had larger internal than external exposure. Adams et al. (2015) recognised that decreasing the infestations at the farm sites with the largest influx of copepodids most efficiently reduced the total amount of lice in an area. By removing/relocating or minimizing the lice burden at the fish farms marked by red in Fig. 12, the fish farms could reduce the need for delousing treatments and the infection pressure on wild fish in the fjord. In general, the simulations indicate that mid-fjord locations are less exposed to salmon lice than those closer to the shore, suggesting that these locations would be more suitable for successful aquaculture activities.

Acknowledgements. The field data used in this research was collected by master students at the University of Tromsø in collaboration with the Institute of Marine Research. Special thanks to Øivind Østensen and Pål Arne Bjørn for assisting with this work.

\section{LITERATURE CITED}

á Norði G, Simonsen K, Danielsen E, Eliasen K and others (2015) Abundance and distribution of planktonic Lepeophtheirus salmonis and Caligus elongatus in a fish farming region in the Faroe Islands. Aquacult Environ Interact $7: 15-27$

> Adams TP, Black KD, MacIntyre C, MacIntyre I, Dean R (2012) Connectivity modelling and network analysis of sea lice infection in Loch Fyne, west coast of Scotland. Aquacult Environ Interact 3:51-63

Adams T, Proud R, Black K (2015) Connected networks of 
sea lice populations: dynamics and implications for control. Aquacult Environ Interact 6:273-284

Albretsen J, Sperrevik AK, Staalstrøm A, Sandvik AD, Vikebø F, Asplin L (2011) NorKyst-800 report no. 1: user manual and technical descriptions. IMR Res Rep Ser Fisken og havet 2/2011. Institute of Marine Research, Bergen

Amundrud TL, Murray AG (2009) Modelling sea lice dispersion under varying environmental forcing in a Scottish sea loch. J Fish Dis 32:27-44

Asplin L, Salvanes AGV, Kristoffersen JB (1999) Nonlocal wind driven fjord-coast advection and its potential effect on plankton and fish recruitment. Fish Oceanogr 8: 255-263

Asplin L, Boxaspen K, Sandvik AD (2004) Modelled distribution of salmon lice in a Norwegian fjord. ICES CM 2004/P:11. International Council for the Exploration of the Sea, Copenhagen

Asplin L, Boxaspen KK, Sandvik AD (2011) Modeling the distribution and abundance of planktonic larval stages of Lepeophtheirus salmonis in Norway. In: Jones $\mathrm{S}$, Beamish R (eds) Salmon lice: an integrated approach to understanding parasite abundance and distribution. Wiley-Blackwell, Oxford, p 31-50

Asplin L, Johnsen IA, Sandvik AD, Albretsen J, Sundfjord V, Aure J, Boxaspen KK (2014) Dispersion of salmon lice in the Hardangerfjord. Mar Biol Res 10:216-225

> Bjorn PA, Finstad B, Kristoffersen R (2001) Salmon lice infection of wild sea trout and Arctic char in marine and freshwaters: the effects of salmon farms. Aquacult Res 32: 947-962

> Brett JR (1965) The relation of size to rate of oxygen consumption and sustained swimming speed of sockeye salmon (Oncorhynchus nerka). J Fish Res Board Can 22: 1491-1501

> Brett JR, Glass NR (1973) Metabolic rates and critical swimming speeds of sockeye salmon (Oncorhynchus nerka) in relation to size and temperature. J Fish Res Board Can 30:379-387

Bricknell IR, Dalesman SJ, O'Shea B, Pert CC, Mordue Luntz AJ (2006) Effect of environmental salinity on sea lice Lepeophtheirus salmonis settlement success. Dis Aquat Org 71:201-212

Bron JE, Sommerville C, Rae GH (1993) Aspects of the behaviour of copepodid larvae of the salmon louse Lepeophtheirus salmonis (Krøyer, 1837). In: Boxshall GA, Defaye D (eds) Pathogens of wild and farmed fish: sea lice. Ellis Horwood, Chichester, p 125-142

Brooks KM (2005) The effects of water temperature, salinity, and currents on the survival and distribution of the infective copepodid stage of sea lice (Lepeophtheirus salmonis) originating on Atlantic salmon farms in the Broughton Archipelago of British Columbia, Canada. Rev Fish Sci 13:177-204

> Burridge L, Weis JS, Cabello F, Pizarro J, Bostick K (2010) Chemical use in salmon aquaculture: a review of current practices and possible environmental effects. Aquaculture 306:7-23

Costello MJ (2006) Ecology of sea lice parasitic on farmed and wild fish. Trends Parasitol 22:475-483

> Costelloe J, Costelloe M, Roche N (1995) Variation in sea lice infestation on Atlantic salmon smolts in Killary Harbour, west coast of Ireland. Aquacult Int 3:379-393

> Dawson LHJ, Pike AW, Houlihan DF, McVicar AH (1998) Effects of salmon lice Lepeophtheirus salmonis on sea trout Salmo trutta at different times after seawater transfer. Dis Aquat Org 33:179-186

Directorate of Fisheries (2013) Forskrift om bekjempelse av lakselus i akvakulturanlegg. Industry and Fisheries Ministry, Bergen

Ellertsen B, Fossum P, Solemdal P, Sundby S, Tilseth S (1984) A case study on the distribution of cod larvae and availability of prey organisms in relation to physical processes in Lofoten. Fløedevigen Rapportserie 1:453-477

> Finstad B, Bjorn PA, Grimnes A, Hvidsten NA (2000) Laboratory and field investigations of salmon lice [Lepeophtheirus salmonis (Kroyer)] infestation on Atlantic salmon (Salmo salar L.) post-smolts. Aquacult Res 31:795-803

Finstad B, Økland F, Thorstad EB, Bjørn PA, McKinley RS (2005) Migration of hatchery reared Atlantic salmon and wild anadromous brown trout post smolts in a Norwegian fjord system. J Fish Biol 66:86-96

Flamarique IN, Browman HI, Belanger $M$, Boxaspen $\mathrm{K}$ (2000) Ontogenetic changes in visual sensitivity of the parasitic salmon louse Lepeophtheirus salmonis. J Exp Biol 203:1649-1657

- Gillibrandt PA, Willis KJ (2007) Dispersal of sea louse larvae from salmon farms: modelling the influence of environmental conditions and larval behaviour. Aquat Biol 1: 63-75

Gravil HR (1996) Studies on the biology and ecology of the free swimming larval stages of Lepeophtheirus salmonis (Kroyer, 1838) and Caligus elongatus Nordmann, 1832 (Copepoda: Caligidae). PhD thesis, University of Stirling

$>$ Heuch PA, Karlsen E (1997) Detection of infrasonic water oscillations by copepodids of Lepeophtheirus salmonis (Copepoda Caligida). J Plankton Res 19:735-747

> Heuch PA, Mo TA (2001) A model of salmon louse production in Norway: effects of increasing salmon production and public management measures. Dis Aquat Org 45: 145-152

Heuch PA, Parsons A, Boxaspen K (1995) Diel vertical migration: a possible host-finding mechanism in salmon louse (Lepeophtheirus salmonis) copepodids? Can J Fish Aquat Sci 52:681-689

Heuch PA, Nordhagen JR, Schram TA (2000) Egg production in the salmon louse [Lepeophtheirus salmonis (Krøyer)] in relation to origin and water temperature. Aquacult Res 31:805-814

Heuch PA, Doall MH, Yen J (2007) Water flow around a fish mimic attracts a parasitic and deters a planktonic copepod. J Plankton Res 29(Suppl 1):i3-i16

Heuch PA, Bjorn PA, Finstad B, Asplin L, Holst JC (2009) Salmon lice infection of farmed and wild salmonids in Norway: an overview. Integr Comp Biol 49:E74

> Heuch PA, Gettinby G, Revie CW (2011) Counting sea lice on Atlantic salmon farms - empirical and theoretical observations. Aquaculture 320:149-153

Hevrøy EM, Boxaspen K, Oppedal F, Taranger GL, Holm JC (2003) The effect of artificial light treatment and depth on the infestation of the sea louse Lepeophtheirus salmonis on Atlantic salmon (Salmo salar L.) culture. Aquaculture 220:1-14

Incze LS, Hebert D, Wolff N, Oakey N, Dye D (2001) Changes in copepod distributions associated with increased turbulence from wind stress. Mar Ecol Prog Ser 213:229-240

> Jackson D, Minchin D (1992) Aspects of the reproductive output of two caligid copepod species parasitic on cultivated salmon. Invertebr Reprod Dev 22:87-90 
Jackson D, Minchin D (1993) Lice infestation of farmed salmon in Ireland. In: Boxshall GA, Defaye D (eds) Pathogens of wild and farmed fish: sea lice. Ellis Horwood, Chichester, p 188-201

> Jensen JLA, Rikardsen AH, Thorstad EB, Suhr AH, Davidsen JG, Primicerio R (2014) Water temperatures influence the marine area use of Salvelinus alpinus and Salmo trutta. J Fish Biol 84:1640-1653

Johannessen A (1977) Early stages of Lepeophtheirus salmonis (Copepoda, Caligidae). Sarsia 63:169-176

Johnsen IA, Fiksen Ø, Sandvik AD, Asplin L (2014) Vertical salmon lice behaviour as a response to environmental conditions and its influence on regional dispersion in a fjord system. Aquacult Environ Interact 5:127-141

Johnson SC, Albright LJ (1991) The developmental stages of Lepeophtheirus salmonis (Krøyer, 1837) (Copepoda: Caligidae). Can J Zool 69:929-950

> Lagadeuc Y, Bouté M, Dodson JJ (1997) Effect of vertical mixing on the vertical distribution of copepods in coastal waters. J Plankton Res 19:1183-1204

McHenery JG, Saward D, Seaton DD (1991) Lethal and sublethal effects of the salmon delousing agent dichlorvos on the larvae of the lobster (Homarus gammarus L.) and herring (Clupea harengus L.). Aquaculture 98:331-347

> McKibben MA, Hay DW (2004) Distributions of planktonic sea lice larvae Lepeophtheirus salmonis in the inter-tidal zone in Loch Torridon, Western Scotland in relation to salmon farm production cycles. Aquacult Res 35:742-750

Middlemas SJ, Stewart DC, Mackay S, Armstrong JD (2009) Habitat use and dispersal of post smolt sea trout Salmo trutta in a Scottish sea loch system. J Fish Biol 74:639-651

Ministry of Trade, Industry and Fisheries (2015) Forutsigbar og miljømessig bærekraftig vekst i norsk lakse- og ørretoppdrett. Meld. St. 16 (2014-2015), Ministry of Trade, Industry and Fisheries, Oslo

> Mitchelson-Jacob G, Sundby S (2001) Eddies of Vestfjorden, Norway. Cont Shelf Res 21:1901-1918

> Murray AG, Gillibrand PA (2006) Modelling salmon lice dispersal in Loch Torridon, Scotland. Mar Pollut Bull 53: 128-135

Murray AG, Amundrud TL, Penston MJ, Pert CC, Middlemas SJ (2011) Abundance and distribution of larval sea lice in Scottish coastal waters. In: Jones S, Beamish R (eds) Salmon lice: an integrated approach to understanding parasite abundance and distribution. Wiley-Blackwell, Oxford, p 51-81

> Myksvoll MS, Sundby S, Ådlandsvik B, Vikebø FB (2011) Retention of coastal cod eggs in a fjord caused by interactions between egg buoyancy and circulation pattern. Mar Coast Fish 3:279-294

> Pemberton R (1976) Sea trout in North Argyll sea lochs, population, distribution and movements. J Fish Biol 9: 157-179

Penston MJ, McKibben MA, Hay DW, Gillibrand PA (2004) Observations on open water densities of sea lice larvae in Loch Shieldaig, western Scotland. Aquacult Res 35: 793-805

> Penston MJ, Millar CP, Zuur A, Davies IM (2008) Spatial and temporal distribution of Lepeophtheirus salmonis (Kroyer) larvae in a sea loch containing Atlantic salmon, Salmo salar L., farms on the north-west coast of Scotland. J Fish Dis 31:361-371

$>$ Pike AW (1989) Sea lice-major pathogens of farmed Atlantic salmon. Parasitol Today 5:291-297

Pike AW, Wadsworth SL (1999) Sealice on salmonids: their biology and control. Adv Parasitol 44:233-337

Pike AW, Mackenzie K, Rowand A (1993) Ultrastructure of the frontal filament in chalimus larvae of Caligus elongatus and Lepeophtheirus salmonis from Atlantic salmon, Salmo salar. In: Boxshall GA, Defaye D (eds) Pathogens of wild and farmed fish: sea lice. Ellis Horwood, Chichester, p 99-113

Rikardsen AH, Diserud OH, Elliott J, Dempson JB, Sturlaugsson J, Jensen AJ (2007) The marine temperature and depth preferences of Arctic charr (Salvelinus alpinus) and sea trout (Salmo trutta), as recorded by data storage tags. Fish Oceanogr 16:436-447

Salama NK, Collins CM, Fraser JG, Dunn J, Pert CC, Murray AG, Rabe B (2013) Development and assessment of a biophysical dispersal model for sea lice. J Fish Dis 36: 323-337

> Salama NKG, Murray AG, Rabe B (2015) Simulated environmental transport distances of Lepeophtheirus salmonis in Loch Linnhe, Scotland, for informing aquaculture area management structures. J Fish Dis, doi:10.1111/jfd.12375

Samsing F, Solstorm D, Oppedal F, Solstorm F, Dempster T (2015) Gone with the flow: current velocities mediate parasitic infestation of an aquatic host. Int J Parasitol 45: 559-565

Schram TA (1993) Supplementary descriptions of the developmental stages of Lepeophtheirus salmonis (Krøyer, 1837) (Copepoda: Caligidae). In: Boxshall GA, Defaye D (eds) Pathogens of wild and farmed fish: sea lice. Ellis Horwood, Chichester, p 30-47

Serra-Llinares RM, Bjørn PA, Finstad B, Nilsen R, Harbitz A, Berg M, Asplin L (2014) Salmon lice infection on wild salmonids in marine protected areas: an evaluation of the Norwegian 'National Salmon Fjords'. Aquacult Environ Interact 5:1-16

Skartveit A, Olseth JA (1988) Varighetstabeller for timevis belysning mot 5 flater på 16 norske stasjoner. Meteorological Report Series 7, University of Bergen

Stien A, Bjørn PA, Heuch PA, Elston DA (2005) Population dynamics of salmon lice Lepeophtheirus salmonis on Atlantic salmon and sea trout. Mar Ecol Prog Ser 290: 263-275

Stigebrandt A, Aure J (1989) Vertical mixing in basin waters of fjords. J Phys Oceanogr 19:917-926

Stormoen M, Skjerve E, Aunsmo A (2013) Modelling salmon lice, Lepeophtheirus salmonis, reproduction on farmed Atlantic salmon, Salmo salar L. J Fish Dis 36:25-33

Stucchi DJ, Guo M, Foreman MGG, Czajko P, Galbraith M, Mackas DL, Gillibrand PA (2011) Modeling sea lice production and concentrations in the Broughton Archipelago, British Columbia. In: Jones S, Beamish R (eds) Salmon lice: an integrated approach to understanding parasite abundance and distribution. Wiley-Blackwell, Oxford, p 117-150

Svedberg HA (2011) The abundance, spatial distribution and dispersion of salmon lice (Lepeophtheirus salmonis, Krøyer) in Folda fjord over two years. MSc thesis, University of Tromsø

Taranger GL, Karlsen Ø, Bannister RJ, Glover KA and others (2014a) Risk assessment of the environmental impact of Norwegian Atlantic salmon farming. ICES J Mar Sci 72: 997-1021

Taranger GL, Svåsand T, Kvamme BO, Kristiansen T, Boxaspen K (2014b) Risikovurdering norsk fiskeoppdrett 2013. Institute of Marine Research, Bergen

Thorstad EB, Økland F, Finstad B, Sivertsgård R, Bjørn PA, 
McKinley RS (2004) Migration speeds and orientation of Atlantic salmon and sea trout post-smolts in a Norwegian fjord system. Environ Biol Fish 71:305-311

Thorstad EB, Økland F, Finstad B, Sivertsgård R, Plantalech N, Bjørn PA, McKinley RS (2007) Fjord migration and survival of wild and hatchery-reared Atlantic salmon and wild brown trout post-smolts. Hydrobiologia 582:99-107

Thorstad EB, Todd CD, Bjørn PA, Gargan PG and others (2014) Effects of salmon lice on sea trout: a literature review. NINA Report 1044, Norwegian Institute for Nature Research, Trondheim

Tucker CS, Sommerville C, Wootten R (2000) The effect of temperature and salinity on the settlement and survival of copepodids of Lepeophtheirus salmonis (Krøyer, 1837)

Editorial responsibility: Bengt Finstad, Trondheim, Norway on Atlantic salmon, Salmo salar L. J Fish Dis 23:309-320

Tully O (1989) The succession of generations and growth of the caligid copepods Caligus elongatus and Lepeophtheirus salmonis parasitising farmed Atlantic salmon smolts (Salmo salar L.). J Mar Biol Assoc UK 69:279-287

Visser AW (1997) Using random walk models to simulate the vertical distribution of particles in a turbulent water column. Mar Ecol Prog Ser 158:275-281

Visser AW, Mariani P, Pigolotti S (2008) Swimming in turbulence: zooplankton fitness in terms of foraging efficiency and predation risk. J Plankton Res 31:121-133

Webb PW, Kostecki PT, Stevens ED (1984) The effect of size and swimming speed on locomotor kinematics of rainbow trout. J Exp Biol 109:77-95

Submitted: June 8, 2015; Accepted: November 5, 2015 Proofs received from author(s): January 22, 2016 